OPEN ACCESS

Edited by:

John Varlotto,

University of Massachusetts

Medical Center, United States

Reviewed by:

Michael T. Milano,

University of Rochester,

United States

Ronald Charles McGarry,

University of Kentucky

HealthCare, United States

*Correspondence:

Nitin Ohri

ohri.nitin@gmail.com

Specialty section:

This article was submitted to

Radiation Oncology,

a section of the journal

Frontiers in Oncology

Received: 08 August 2017

Accepted: 23 August 2017

Published: 21 September 2017

Citation:

Ohri N (2017) Radiotherapy Dosing

for Locally Advanced Non-Small Cell

Lung Carcinoma:

"MTD" or "ALARA"?

Front. Oncol. 7:205.

doi: 10.3389/fonc.2017.00205

\section{Radiotherapy Dosing for Locally Advanced Non-Small Cell Lung Carcinoma: "MTD" or "ALARA"?}

\author{
Nitin Ohri ${ }^{1,2 *}$ \\ ${ }^{1}$ Radiation Oncology, Albert Einstein College of Medicine, The Bronx, NY, United States, ${ }^{2}$ Radiation Oncology, Montefiore \\ Medical Center, The Bronx, NY, United States
}

Locally advanced non-small cell lung cancer (LA-NSCLC) is typically treated with thoracic radiotherapy, often in combination with cytotoxic chemotherapy. Despite tremendous advances in the evaluation, treatment techniques, and supportive care measures provided to LA-NSCLC patients, local disease progression and distant metastases frequently develop following definitive therapy. A recent landmark randomized trial demonstrated that radiotherapy dose escalation may reduce survival rates, highlighting our poor understanding of the effects of thoracic radiotherapy for LA-NSCLC. Here, we present rationale for further studies of radiotherapy dose escalation as well as arguments for exploring relatively low radiotherapy doses for LA-NSCLC.

Keywords: locally advanced NSCLC, radiotherapy, dose-response relationship, radiation, chemoradiotherapy, lung cancer

\section{BACKGROUND}

Non-small cell lung cancer (NSCLC) is the leading cause of cancer mortality in the United States and worldwide, causing over one million deaths each year (1). Approximately one-third of NSCLC patients are diagnosed with locally advanced disease, which may be defined as stage III disease or unresectable stage II disease (2). For locally advanced non-small cell lung cancer (LA-NSCLC), the standard treatment approach is conventionally fractionated (1.8-2.0 Gy/day) radiotherapy to a dose of approximately $60-66$ Gy with concurrent, platinum-based chemotherapy. This treatment approach yields median survival times of only 16-30 months. Randomized trials have tested changes or additions to systemic therapy (3-7), radiotherapy dose escalation (6), and the addition of surgical resection (8) but have failed to improve overall survival for this patient population.

In this review, we will focus on the question of radiotherapy dosing for LA-NSCLC. Dozens of trials have sought to identify the optimal dosing schedule through modifications of the total radiotherapy dose, the daily radiotherapy dose, and treatment frequency $(9,10)$. However, tremendous uncertainty persists regarding the optimal radiotherapy regimen for LA-NSCLC. As an infinite number of radiotherapy schedules could be an envisioned, we will simplify our discussion by considering two opposing viewpoints: "maximum tolerated dose" (MTD) and "as low as reasonably achievable" (ALARA).

Maximum tolerated dose is defined by the National Cancer Institute as follows: "The highest dose of a drug or treatment that does not cause unacceptable side effects. The MTD is determined in clinical trials by testing increasing doses on different groups of people until the highest dose with acceptable side effects is found." (11) The United States Nuclear Regulatory Commission states that "ALARA is an acronym for as low as (is) reasonably achievable, which means making every 
reasonable effort to maintain exposures to ionizing radiation as far below the dose limits as practical, consistent with the purpose for which the licensed activity is undertaken..." (12) ALARA is most often used in the context of environmental or occupational radiation exposure. For the purposes of this exercise, we will consider ALARA to represent the delivery of the lowest possible radiotherapy dose for LA-NSCLC that does not compromise local disease control probability.

\section{FACT: DISEASE PROGRESSION FOLLOWING CHEMORADIOTHERAPY FOR LA-NSCLC IS COMMON}

\section{Supporting MTD}

Chemoradiotherapy for LA-NSCLC yields local control rates of only $40-66 \%(6,13-17)$. At least $75 \%$ of LA-NSCLC patients will succumb to their disease (6). While distant disease progression is a competing risk for LA-NSCLC that may theoretically detract from the importance of local control, there is high-level evidence that improving local control will directly improve survival rates. In a meta-analysis of six randomized trials comparing concurrent chemoradiotherapy to sequential chemoradiotherapy, the use of concurrent chemoradiotherapy increased the 5 -year locoregional control rate by $6 \%$ at 5 years and improved the overall survival rate by $5 \%$ at 5 years, without reducing the frequency of distant metastasis (18). Thus, there seems to be a nearly 1:1 ratio linking locoregional disease control and overall survival in LA-NSCLC. This may be compared with the 4:1 ratio that has been established in the treatment of breast cancer with postoperative radiotherapy (19). The importance of local control in LA-NSCLC may become even more important in the future, as novel and more effective systemic therapy (20-22) may be incorporated into the management of LA-NSCLC (23) and attenuate the competing risk of distant metastasis.

Radiotherapy dose escalation or intensification using altered fractionation has been shown to improve disease control in cancers of the prostate (24) and head and neck (25). Altered radiotherapy fractionation for LA-NSCLC has also been shown to improve outcomes to some extent in large, randomized clinical trials (26). Established radiobiological principles indicate that intensified radiotherapy is required to sterilize lung tumors, where hypoxia and accelerated repopulation contribute to radioresistance (27). For early stage lung cancer, hypofractionated stereotactic body radiotherapy (SBRT) yields excellent control rates, particularly when high biologically effective doses are delivered $(28,29)$. Advances in radiotherapy treatment planning and delivery should be leveraged in a similar fashion to safely deliver curative radiotherapy doses for LA-NSCLC. While RTOG 0617 demonstrated that radiotherapy dose escalation applied to large volumes using conventional fractionation does not improve outcomes in LA-NSCLC (6), more innovative strategies to intensify radiotherapy using adaptive planning (30), SBRT boost (31), and particle therapy $(32,33)$ must be explored to improve outcomes for patients with LA-NSCLC.

\section{Supporting ALARA}

Distant metastasis occurs within two years in the majority of LA-NSCLC patients who are treated with concurrent chemoradiotherapy with definitive intent (6). Thoracic radiotherapy, which can cause profound acute $(34,35)$ and subacute $(36,37)$ toxicities in a dose-dependent fashion, should therefore be administered cautiously in this patient population. The current "standard" schedule of 60 Gy in 30 fractions was established approximately 40 years ago in a landmark randomized trial (38). 60 Gy was chosen over 50 Gy because 60 Gy yielded slightly better (but not statistically significantly superior) outcomes with respect to overall survival and local disease control. The relevance of these findings to current practice, where LA-NSCLC patients are treated with vastly more advanced techniques and typically receive concurrent chemotherapy, is unclear.

Several retrospective studies demonstrated strong associations between radiotherapy dose and overall survival duration, including in patients receiving concurrent chemotherapy (39, 40). In light of the results of RTOG 0617, however, it appears likely that those associations are attributable to selection biases (e.g., treating smaller volume disease with higher doses) or advances in treatment techniques (41) and systemic therapy (42) that took place during the era when non-randomized dose escalation trials were performed. Notably, RTOG 0617 (6) and several other trials where chemoradiotherapy was intensified using altered radiotherapy fractionation $(9,10)$ failed to demonstrate that local disease control or overall survival is improved with more aggressive radiotherapy. Meta-analyses strongly suggest that radiotherapy intensification may be beneficial when radiotherapy is delivered without chemotherapy but has not improved outcomes in the setting of concurrent chemotherapy $(9,10)$. The ability to control LA-NSCLC with chemoradiotherapy may more closely be related to tumor biology (43) and disease burden (44) than with radiotherapy dose. One may therefore argue that clinical trials should seek to define the lowest radiotherapy dose that can be used to treat LA-NSCLC without meaningfully compromising the likelihood of local disease control. An adaptive study design, such as the time-to-event continual reassessment model (45) could be could be ideal for defining a "minimum tolerated dose" in this setting. Based on analyzes of recurrence patterns demonstrating that local disease progression typically occurs in regions with large initial disease burden (46), a dose-painting approach may be implemented to reduce the dose delivered to small tumors and lymph nodes. In the rare cases where isolated thoracic disease progression occurs, salvage treatment options such as SBRT may yield excellent rates of disease control with acceptable toxicity rates (47).

\section{FACT: SERIOUS COMPLICATION RATES FOLLOWING THORACIC RADIOTHERAPY FOR LA-NSCLC ARE LOW}

\section{Supporting MTD}

The elimination of elective nodal irradiation (48), advances in imaging and target delineation (49), and advances in treatment techniques have significantly reduced the toxicity profile 
of thoracic irradiation (50). Two dose escalation studies demonstrated that treatment with 74 Gy in 37 daily fractions with concurrent carboplatin and paclitaxel is safe (51,52), leading to the use of that regimen in the experimental arm of RTOG 0617. In RTOG 0617, rates of severe (grade $\geq 3$ ) toxicities were essentially equal across the control (60 Gy) and experimental (74 Gy) arms, demonstrating that modern treatment techniques and evidence-based constraints can be implemented to allow the safe delivery of dose-escalated thoracic radiotherapy. Complication rates may be expected to decline in future trials, as intensity-modulated radiotherapy and particle radiotherapy are increasingly being implemented for the treatment of LA-NSCLC $(32,53)$. Esophagitis is one important acute complication of thoracic radiotherapy that occurs in a dose-dependent fashion $(6,34)$. With modern treatment techniques and supportive care measures, however, most patients can complete radiotherapy without a treatment break (54).

\section{Supporting ALARA}

Evolving evidence reveals that thoracic irradiation can have profound consequences that were previously not appreciated. Two examples are provided below. As these risks emerge in a dose-dependent fashion, it is imperative that we examine the relationship between radiotherapy dosing and outcomes in LA-NSCLC rigorously and without bias and implement the lowest dose required to achieve local disease control.

Across the field of Oncology, patient-reported outcomes (PROs) have emerged as a key tool for assessing individual patients as well as in evaluating novel treatment strategies. PROs may be particularly revealing in the setting of LA-NSCLC, where patients' health status may be compromised by underlying comorbidities, disease burden, and treatment toxicity. In a key secondary analysis of RTOG 0617, treatment with 74 Gy rather than 60 Gy dramatically increased the risk of meaningful quality of life decline at 3 months (55). Baseline quality of life scores were also found to be significant predictors of overall survival on multivariable analyses. The "safety" of high-dose thoracic radiotherapy should be reexamined using PROs. Existing data indicate that patient-reported toxicity rates will differ dramatically from clinician-scored adverse event rates (56), particularly in the setting of dose-escalated radiotherapy.

A growing body of literature indicates that minimizing cardiac irradiation should be a goal in planning thoracic radiotherapy. Recent publications have demonstrated a strong association between cardiac irradiation and both cardiac events $(36,37,57$, 58) and all-cause mortality (6). The risks of cardiac irradiation may be highest in subjects with comorbid conditions such as existing heart disease $(36,37)$ or a smoking history $(58)$, which are common in NSCLC patients. Somewhat surprisingly, these effects have been seen within a few years of radiotherapy delivery $(6,36,37,57)$ and in populations with high risk of cancer-specific mortality $(6,36,37)$. In retrospect, this is consistent with previous analyses demonstrating that excessive (59) or unnecessary (60) mediastinal irradiation for lung cancer can meaningfully reduce survival rates. Thoracic irradiation may directly lead to coronary artery stenosis (61) and may also impair patients' immune systems (62).

\section{FACT: SYSTEMIC THERAPY FOR NSCLC IS EVOLVING RAPIDLY}

\section{Supporting MTD}

Targeted therapy and immunotherapy are revolutionizing the management of advanced NSCLC $(20,63)$. As these agents are incorporated into the management of LA-NSCLC $(23,64)$, one may expect the rate of distant metastasis to improve significantly. This could magnify the importance of achieving durable local disease control with effective radiotherapy. If induction therapy is utilized to reduce target volumes before delivery of thoracic radiotherapy, dose escalation with conventional or even stereotactic radiotherapy techniques would be particularly appealing.

Immunotherapy may be an ideal partner for high-dose radiotherapy. Radiotherapy may enhance tumor antigen presentation, increase cytokine production, and modulate the tumor microenvironment, promoting antitumor immunity $(65,66)$. Numerous preclinical studies $(67,68)$ and case reports $(68-71)$ have demonstrated that there may be synergy between radiotherapy and immunotherapy. These effects may be maximized by employing "ablative" radiotherapy schedules, avoiding prolonged treatment courses, minimizing incidental irradiation of regional lymph nodes and other organs, and utilization of heavy ion radiotherapy $(72,73)$.

\section{Supporting ALARA}

For appropriately selected patients with advanced NSCLC, targeted therapy (74) or immunotherapy (20) yields far higher response rates and more durable disease control than cytotoxic chemotherapy. If similar responses are seen in LA-NSCLC, relatively low radiotherapy doses may be required to provide high rates of local disease control. On a patient level, tumor characterization and molecular subtyping will be facilitated by liquid biopsies (75). Functional imaging $(46,76)$ and radiomic analyses $(77,78)$ will also aid in identifying patients and specific tumors or lymph nodes where disease is likely to be controlled without receiving high radiotherapy doses. It is imperative that radiation oncologists continuously reassess the relationship between radiotherapy dose and local disease control, as NSCLC is increasingly understood represent a mosaic of heterogeneous diseases rather than a single disorder. At the same time, novel systemic agents may unexpectedly modulate the toxicity profile of thoracic radiotherapy $(79,80)$ such that modest radiotherapy doses optimize the risk/benefit ratio of thoracic irradiation for LA-NSCLC. Therefore, the relationship between radiotherapy doses and toxicity risk must also be reassessed frequently, preferably in trials designed to account for subacute and delayed adverse events (81).

\section{CONCLUSION}

Decades of clinical trials have not changed in the "standard" radiotherapy dosing for LA-NSCLC. However, it remains unlikely that current practices yield optimal results, and it is impossible to believe that a single dosing regimen should be administered to every patient with LA-NSCLC. The effects of radiotherapy dosing on both disease control probability and complication probability 
must be reassessed as new systemic treatment options emerge and as new subtypes of NSCLC are recognized. PROs may provide more meaningful information that physician-scored toxicity rates and should be incorporated into all NSCLC trials.

\section{REFERENCES}

1. Jemal A, Bray F, Center MM, Ferlay J, Ward E, Forman D. Global cancer statistics. CA Cancer J Clin (2011) 61:69-90. doi:10.3322/caac.20107

2. Goldstraw P, Crowley J, Chansky K, Giroux DJ, Groome PA, Rami-Porta R, et al. The IASLC lung cancer staging project: proposals for the revision of the TNM stage groupings in the forthcoming (seventh) edition of the TNM classification of malignant tumours. J Thorac Oncol (2007) 2:706-14. doi:10.1097/ JTO.0b013e31812f3cla

3. Vokes EE, Herndon JE, Kelley MJ, Cicchetti MG, Ramnath N, Neill H, et al. Induction chemotherapy followed by chemoradiotherapy compared with chemoradiotherapy alone for regionally advanced unresectable stage III non-small-cell lung cancer: cancer and leukemia group B. J Clin Oncol (2007) 25:1698. doi:10.1200/JCO.2006.07.3569

4. Hanna N, Neubauer M, Yiannoutsos C, McGarry R, Arseneau J, Ansari R, et al. Phase III study of cisplatin, etoposide, and concurrent chest radiation with or without consolidation docetaxel in patients with inoperable stage III non-small-cell lung cancer: the Hoosier Oncology Group and U.S. Oncology. J Clin Oncol (2008) 26:5755-60. doi:10.1200/JCO.2008.17.7840

5. Kelly K, Chansky K, Gaspar LE, Albain KS, Jett J, Ung YC, et al. Phase III trial of maintenance gefitinib or placebo after concurrent chemoradiotherapy and docetaxel consolidation in inoperable stage III non-small-cell lung cancer: SWOG S0023. J Clin Oncol (2008) 26:2450-6. doi:10.1200/JCO.2007.14.4824

6. Bradley JD, Paulus R, Komaki R, Masters G, Blumenschein G, Schild S, et al. Standard-dose versus high-dose conformal radiotherapy with concurrent and consolidation carboplatin plus paclitaxel with or without cetuximab for patients with stage IIIA or IIIB non-small-cell lung cancer (RTOG 0617): a randomised, two-by-two factorial phase 3 study. Lancet Oncol (2015) 16:187-99. doi:10.1016/S1470-2045(14)71207-0

7. Senan S, Brade A, Wang L-H, Vansteenkiste J, Dakhil S, Biesma B, et al. PROCLAIM: randomized phase III trial of pemetrexed-cisplatin or etoposide-cisplatin plus thoracic radiation therapy followed by consolidation chemotherapy in locally advanced nonsquamous non-small-cell lung cancer. J Clin Oncol (2016) 34:953-62. doi:10.1200/JCO.2015.64.8824

8. Albain KS, Swann RS, Rusch VW, Turrisi AT 3rd, Shepherd FA, Smith C, et al. Radiotherapy plus chemotherapy with or without surgical resection for stage III non-small-cell lung cancer: a phase III randomised controlled trial. Lancet (2009) 374:379-86. doi:10.1016/S0140-6736(09)60737-6

9. Yamoah K, Showalter TN, Ohri N. Radiation therapy intensification for solid tumors: a systematic review of randomized trials. Int J Radiat Oncol Biol Phys (2015) 93:737-45. doi:10.1016/j.ijrobp.2015.07.2284

10. Ramroth J, Cutter DJ, Darby SC, Higgins GS, McGale P, Partridge M, et al. Dose and fractionation in radiation therapy of curative intent for non-small cell lung cancer: meta-analysis of randomized trials. Int J Radiat Oncol Biol Phys (2016) 96:736-47. doi:10.1016/j.ijrobp.2016.07.022

11. National Cancer Institute. NCI Dictionary of Cancer Terms. (2017).

12. United States Nuclear Regulatory Commission. ALARA. (2017).

13. Belani CP, Choy H, Bonomi P, Scott C, Travis P, Haluschak J, et al. Combined chemoradiotherapy regimens of paclitaxel and carboplatin for locally advanced non-small-cell lung cancer: a randomized phase II locally advanced multi-modality protocol. JClin Oncol (2005) 23:5883-91. doi:10.1200/ JCO.2005.55.405

14. Fournel P, Robinet G, Thomas P, Souquet PJ, Léna H, Vergnenégre A, et al. Randomized phase III trial of sequential chemoradiotherapy compared with concurrent chemoradiotherapy in locally advanced non-small-cell lung cancer: Groupe Lyon-Saint-Etienne d'Oncologie Thoracique-Groupe Francais de Pneumo-Cancérologie NPC 95-01 study. JClin Oncol (2005) 23:5910. doi:10.1200/JCO.2005.03.070

15. Furuse K, Fukuoka M, Kawahara M, Nishikawa H, Takada Y, Kudoh S, et al. Phase III study of concurrent versus sequential thoracic radiotherapy in combination with mitomycin, vindesine, and cisplatin in unresectable stage

\section{AUTHOR CONTRIBUTIONS}

The lead author (NO) was responsible for designing and writing this review article.
III non-small-cell lung cancer. J Clin Oncol (1999) 17:2692. doi:10.1200/ JCO.1999.17.9.2692

16. Zatloukal P, Petruzelka L, Zemanova M, Havel L, Janku F, Judas L, et al. Concurrent versus sequential chemoradiotherapy with cisplatin and vinorelbine in locally advanced non-small cell lung cancer: a randomized study. Lung Cancer (2004) 46:87-98. doi:10.1016/j.lungcan.2004.03.004

17. Curran WJ Jr, Paulus R, Langer CJ, Komaki R, Lee JS, Hauser S, et al. Sequential vs. concurrent chemoradiation for stage III non-small cell lung cancer: randomized phase III trial RTOG 9410. J Natl Cancer Inst (2011) 103:1452-60. doi:10.1093/jnci/djr325

18. Aupérin A, Le Péchoux C, Rolland E, Curran WJ, Furuse K, Fournel P, et al. Meta-analysis of concomitant versus sequential radiochemotherapy in locally advanced non-small-cell lung cancer. J Clin Oncol (2010) 28:2181-90. doi:10.1200/JCO.2009.26.2543

19. Group EBCTC. Effects of radiotherapy and of differences in the extent of surgery for early breast cancer on local recurrence and 15-year survival: an overview of the randomised trials. Lancet (2006) 366:2087-106. doi:10.1016/ S0140-6736(05)67887-7

20. Reck M, Rodríguez-Abreu D, Robinson AG, Hui R, Csőszi T, Fülöp A, et al. Pembrolizumab versus chemotherapy for PD-L1-positive non-small-cell lung cancer. N Engl J Med (2016) 375:1823-33. doi:10.1056/NEJMoa1606774

21. Borghaei H, Paz-Ares L, Horn L, Spigel DR, Steins M, Ready NE, et al. Nivolumab versus docetaxel in advanced nonsquamous non-small-cell lung cancer. N Engl J Med (2015) 373:1627-39. doi:10.1056/NEJMoa1507643

22. Brahmer J, Reckamp KL, Baas P, Crinò L, Eberhardt WE, Poddubskaya E, et al. Nivolumab versus docetaxel in advanced squamous-cell non-small-cell lung cancer. N Engl J Med (2015) 373:123-35. doi:10.1056/NEJMoa1504627

23. Gerber DE, Urbanic JJ, Langer C, Hu C, Chang IF, Lu B, et al. Treatment design and rationale for a randomized trial of cisplatin and etoposide plus thoracic radiotherapy followed by nivolumab or placebo for locally advanced non-small-cell lung cancer (RTOG 3505). Clin Lung Cancer (2017) 18:333-9. doi:10.1016/j.cllc.2016.10.009

24. Viani GA, Stefano EJ, Afonso SL. Higher-than-conventional radiation doses in localized prostate cancer treatment: a meta-analysis of randomized, controlled trials. Int J Radiat Oncol Biol Phys (2009) 74:1405-18. doi:10.1016/j. ijrobp.2008.10.091

25. Pignon JP, le Maître A, Maillard E, Bourhis J, Group M-NC. Meta-analysis of chemotherapy in head and neck cancer (MACH-NC): an update on 93 randomised trials and 17,346 patients. Radiother Oncol (2009) 92:4-14. doi:10.1016/j.radonc.2009.04.014

26. Mauguen A, Le Péchoux C, Saunders MI, Schild SE, Turrisi AT, Baumann M, et al. Hyperfractionated or accelerated radiotherapy in lung cancer: an individual patient data meta-analysis. J Clin Oncol (2012) 30:2788-97. doi:10.1200/ JCO.2012.41.6677

27. Bazan JG, Le Q-T, Zips D. Radiobiology of Lung Cancer. Iaslc Thoracic Oncology E-Book. (2017). 330 p.

28. Onishi H, Araki T, Shirato H, Nagata Y, Hiraoka M, Gomi K, et al. Stereotactic hypofractionated high-dose irradiation for stage I nonsmall cell lung carcinoma. Cancer (2004) 101:1623-31. doi:10.1002/cncr.20539

29. Ohri N, Werner-Wasik M, Grills IS, Belderbos J, Hope A, Yan D, et al. Modeling local control after hypofractionated stereotactic body radiation therapy for stage I non-small cell lung cancer: a report from the elekta collaborative lung research group. Int J Radiat Oncol Biol Phys (2012) 84:e379-84. doi:10.1016/j. ijrobp.2012.04.040

30. Kong F-M, Ten Haken RK, Schipper M, Frey KA, Hayman J, Gross M, et al. Effect of midtreatment PET/CT-adapted radiation therapy with concurrent chemotherapy in patients with locally advanced non-small-cell lung cancer: a phase 2 clinical trial. JAMA Oncol (2017). doi:10.1001/jamaoncol.2017.0982

31. McGarry R, Feddock J. A prospective study of SBRT boost to residual disease in stage III NSCLC: updated results. Int J Radiat Oncol Biol Phys (2014) 90:S651. doi:10.1016/j.ijrobp.2014.05.1925 
32. Higgins KA, O’Connell K, Liu Y, Gillespie TW, McDonald MW, Pillai RN, et al. National cancer database analysis of proton versus photon radiation therapy in non-small cell lung cancer. Int J Radiat Oncol Biol Phys (2017) 97:128-37. doi:10.1016/j.ijrobp.2016.10.001

33. Shirai K, Kawashima M, Saitoh J-I, Abe T, Fukata K, Shigeta Y, et al. Clinical outcomes using carbon-ion radiotherapy and dose-volume histogram comparison between carbon-ion radiotherapy and photon therapy for T2b-4N0M0 non-small cell lung cancer - a pilot study. PLoS One (2017) 12:e0175589. doi:10.1371/journal.pone.0175589

34. Palma DA, Senan S, Oberije C, Belderbos J, de Dios NR, Bradley JD, et al. Predicting esophagitis after chemoradiation therapy for non-small cell lung cancer: an individual patient data meta-analysis. Int J Radiat Oncol Biol Phys (2013) 87:690-6. doi:10.1016/j.ijrobp.2013.07.029

35. Bar-Ad V, Ohri N, Werner-Wasik M. Esophagitis, treatment-related toxicity in non-small cell lung cancer. Rev Recent Clin Trials (2012) 7:31-5. doi:10.2174/157488712799363235

36. Wang K, Eblan M), Deal AM, Lipner M, Zagar TM, Wang Y, et al. Cardiac toxicity after radiotherapy for stage III non-small-cell lung cancer: pooled analysis of dose-escalation trials delivering 70 to 90 Gy. J Clin Oncol (2017) 35:1387-94. doi:10.1200/JCO.2016.70.0229

37. Dess RT, Sun Y, Matuszak MM, Sun G, Soni PD, Bazzi L, et al. Cardiac events after radiation therapy: combined analysis of prospective multicenter trials for locally advanced non-small-cell lung cancer. J Clin Oncol (2017) 35:1395-402. doi:10.1200/JCO.2016.71.6142

38. Perez CA, Stanley K, Rubin P, Kramer S, Brady L, Perez-Tamayo R, et al. A prospective randomized study of various irradiation doses and fractionation schedules in the treatment of inoperable non-oat-cell carcinoma of the lung. Preliminary report by the Radiation Therapy Oncology Group. Cancer (1980) 45:2744-53. doi:10.1002/1097-0142(19800601)45:11<2744::AID-CNCR2820451108>3.0.CO;2-U

39. Machtay M, Bae K, Movsas B, Paulus R, Gore EM, Komaki R, et al. Higher biologically effective dose of radiotherapy is associated with improved outcomes for locally advanced non-small cell lung carcinoma treated with chemoradiation: an analysis of the Radiation Therapy Oncology Group. Int J Radiat Oncol Biol Phys (2012) 82:425-34. doi:10.1016/j.ijrobp. 2010.09.004

40. Brower JV, Amini A, Chen S, Hullett CR, Kimple RJ, Wojcieszynski AP, et al. Improved survival with dose-escalated radiotherapy in stage III non-smallcell lung cancer: analysis of the National Cancer Database. Ann Oncol (2016) 27:1887-94. doi:10.1093/annonc/mdw276

41. Liao ZX, Komaki RR, Thames HD, Liu HH, Tucker SL, Mohan R, et al. Influence of technologic advances on outcomes in patients with unresectable, locally advanced non-small-cell lung cancer receiving concomitant chemoradiotherapy. Int J Radiat Oncol Biol Phys (2010) 76:775-81. doi:10.1016/j. ijrobp.2009.02.032

42. Zhou C, Wu Y-L, Chen G, Feng J, Liu X-Q, Wang C, et al. Erlotinib versus chemotherapy as first-line treatment for patients with advanced EGFR mutation-positive non-small-cell lung cancer (OPTIMAL, CTONG-0802): a multicentre, open-label, randomised, phase 3 study. Lancet Oncol (2011) 12:735-42. doi:10.1016/S1470-2045(11)70184-X

43. Scott JG, Berglund A, Schell MJ, Mihaylov I, Fulp WJ, Yue B, et al. A genome-based model for adjusting radiotherapy dose (GARD): a retrospective, cohort-based study. Lancet Oncol (2017) 18:202-11. doi:10.1016/ S1470-2045(16)30648-9

44. Ohri N, Duan F, Machtay M, Gorelick JJ, Snyder BS, Alavi A, et al. Pretreatment FDG-PET metrics in stage III non-small cell lung cancer: ACRIN 6668/RTOG 0235. J Natl Cancer Inst (2015) 107:djv004. doi:10.1093/ jnci/djv004

45. Iasonos A, O'Quigley J. Adaptive dose-finding studies: a review of model-guided phase I clinical trials. J Clin Oncol (2014) 32:2505-11. doi:10.1200/ JCO.2013.54.6051

46. Ohri N, Bodner WR, Halmos B, Cheng H, Perez-Soler R, Keller SM, et al. 18 F-fluorodeoxyglucose/positron emission tomography predicts patterns of failure after definitive chemoradiation therapy for locally advanced non-small cell lung cancer. Int J Radiat Oncol Biol Phys (2017) 97:372-80. doi:10.1016/j. ijrobp.2016.10.031

47. Amendola BE, Amendola MA, Perez N, Wu X, Suarez JB. Local failure after primary radiotherapy in lung cancer: is there a role for SBRT? Rep Pract Oncol Radiother (2015) 20:440-5. doi:10.1016/j.rpor.2015.08.001
48. Yuan S, Sun X, Li M, Yu J, Ren R, Yu Y, et al. A randomized study of involved-field irradiation versus elective nodal irradiation in combination with concurrent chemotherapy for inoperable stage III nonsmall cell lung cancer. Am J Clin Oncol (2007) 30:239-44. doi:10.1097/01.coc.0000256691. 27796.24

49. Bradley J, Bae K, Choi N, Forster K, Siegel BA, Brunetti J, et al. A phase II comparative study of gross tumor volume definition with or without PET/CT fusion in dosimetric planning for non-small-cell lung cancer (NSCLC): primary analysis of Radiation Therapy Oncology Group (RTOG) 0515. Int J Radiat Oncol Biol Phys (2012) 82(435-41):e1. doi:10.1016/j.ijrobp.2010.09.033

50. Chun SG, Hu C, Choy H, Komaki RU, Timmerman RD, Schild SE, et al. Impact of intensity-modulated radiation therapy technique for locally advanced non-small-cell lung cancer: a secondary analysis of the NRG oncology RTOG 0617 randomized clinical trial. J Clin Oncol (2017) 35:56-62. doi:10.1200/JCO.2016.69.1378

51. Schild SE, Hillman SL, Tan AD, Ross HJ, McGinnis WL, Garces YA, et al. Long-term results of a trial of concurrent chemotherapy and escalating doses of radiation for unresectable non-small cell lung cancer: NCCTG N0028 (alliance). J Thorac Oncol (2017) 12:697-703. doi:10.1016/j.jtho.2016. 12.021

52. Bradley J, Graham M, Suzanne S, Byhardt R, Govindan R, Fowler J, et al. Phase I results of RTOG L-0117; a phase I/II dose intensification study using 3DCRT and concurrent chemotherapy for patients with inoperable NSCLC. JClin Oncol (2005) 23:7063-7063. doi:10.1200/jco.2005.23.16_suppl.7063

53. Shirvani SM, Jiang J, Gomez DR, Chang JY, Buchholz TA, Smith BD. Intensity modulated radiotherapy for stage III non-small cell lung cancer in the United States: predictors of use and association with toxicities. Lung Cancer (2013) 82:252-9. doi:10.1016/j.lungcan.2013.08.015

54. McMillan MT, Ojerholm E, Verma V, Higgins KA, Singhal S, Predina JD, et al. Radiotherapy treatment time and overall survival in locally advanced non-small cell lung cancer. Int J Radiat Oncol Biol Phys (2017) 98:1142-52. doi:10.1016/j.ijrobp.2017.04.004

55. Movsas B, Hu C, Sloan J, Bradley J, Komaki R, Masters G, et al. Quality of life analysis of a radiation dose-escalation study of patients with non-small-cell lung cancer: a secondary analysis of the radiation therapy oncology group 0617 randomized clinical trial. JAMA Oncol (2016) 2:359-67. doi:10.1001/ jamaoncol.2015.3969

56. Fogh S, Deshmukh S, Berk LB, Dueck AC, Roof K, Yacoub S, et al. A randomized phase II trial of prophylactic manuka honey for the reduction of chemoradiation therapy induced esophagitis during the treatment of lung cancer: results of trial. Int J Radiat Oncol Biol Phys (2017) 97:786-96. doi:10.1016/j. ijrobp.2016.11.022

57. Darby SC, Ewertz M, McGale P, Bennet AM, Blom-Goldman U, Brønnum D, et al. Risk of ischemic heart disease in women after radiotherapy for breast cancer. N Engl J Med (2013) 368:987-98. doi:10.1056/NEJMoa1209825

58. Taylor C, Correa C, Duane FK, Aznar MC, Anderson SJ, Bergh J, et al. Estimating the risks of breast cancer radiotherapy: evidence from modern radiation doses to the lungs and heart and from previous randomized trials. J Clin Oncol (2017) 35:1641-9. doi:10.1200/JCO.2016.72.0722

59. Machtay M, Lee JH, Shrager JB, Kaiser LR, Glatstein E. Risk of death from intercurrent disease is not excessively increased by modern postoperative radiotherapy for high-risk resected non-small-cell lung carcinoma. JClin Oncol (2001) 19:3912-7. doi:10.1200/JCO.2001.19.19.3912

60. Group PM-AT. Postoperative radiotherapy in non-small-cell lung cancer: systematic review and meta-analysis of individual patient data from nine randomised controlled trials. Lancet (1998) 352:257-63. doi:10.1016/ S0140-6736(98)06341-7

61. Nilsson G, Holmberg L, Garmo H, Duvernoy O, Sjögren I, Lagerqvist B, et al. Distribution of coronary artery stenosis after radiation for breast cancer. J Clin Oncol (2011) 30:380-6. doi:10.1200/JCO.2011.34.5900

62. Tang C, Liao Z, Gomez D, Levy L, Zhuang Y, Gebremichael RA, et al. Lymphopenia association with gross tumor volume and lung V5 and its effects on non-small cell lung cancer patient outcomes. Int J Radiat Oncol Biol Phys (2014) 89:1084-91. doi:10.1016/j.ijrobp.2014.04.025

63. Mok TS, Wu Y-L, Ahn M-J, Garassino MC, Kim HR, Ramalingam SS, et al. Osimertinib or platinum-pemetrexed in EGFR T790M-positive lung cancer. N Engl J Med (2017) 376:629-40. doi:10.1056/NEJMoa1612674

64. Xing L, Wu G, Wang L, Li J-C, Wang J, Yuan Z, et al. A multicenter, randomized, open-label, phase II trial of erlotinib versus etoposide plus cisplatin 
with concurrent radiotherapy in unresectable stage III non-small cell lung cancer (NSCLC) with epidermal growth factor receptor (EGFR) activating mutation. Am Soc Clin Oncol (2017) 35(15 Suppl):8531. doi:10.1200/ JCO.2017.35.15_suppl.8531

65. Bernstein MB, Krishnan S, Hodge JW, Chang JY. Immunotherapy and stereotactic ablative radiotherapy (ISABR): a curative approach? Nat Rev Clin Oncol (2016) 13:516-24. doi:10.1038/nrclinonc.2016.30

66. Formenti SC, Demaria S. Combining radiotherapy and cancer immunotherapy: a paradigm shift. J Natl Cancer Inst (2013) 105:256-65. doi:10.1093/jnci/ djs 629

67. Chakravarty PK, Alfieri A, Thomas EK, Beri V, Tanaka KE, Vikram B, et al. Flt3-ligand administration after radiation therapy prolongs survival in a murine model of metastatic lung cancer. Cancer Res (1999) 59:6028-32.

68. Dovedi SJ, Adlard AL, Lipowska-Bhalla G, McKenna C, Jones S, Cheadle EJ, et al. Acquired resistance to fractionated radiotherapy can be overcome by concurrent PD-L1 blockade. Cancer Res (2014) 74:5458-68. doi:10.1158/00085472.CAN-14-1258

69. Postow MA, Callahan MK, Barker CA, Yamada Y, Yuan J, Kitano S, et al. Immunologic correlates of the abscopal effect in a patient with melanoma. N Engl J Med (2012) 366:925-31. doi:10.1056/NEJMoa1112824

70. Golden EB, Demaria S, Schiff PB, Chachoua A, Formenti SC. An abscopal response to radiation and ipilimumab in a patient with metastatic non-small cell lung cancer. Cancer Immunol Res (2013) 1:365-72. doi:10.1158/23266066.CIR-13-0115

71. Hiniker SM, Chen DS, Reddy S, Chang DT, Jones JC, Mollick JA, et al. A systemic complete response of metastatic melanoma to local radiation and immunotherapy. Transl Oncol (2012) 5:404-7. doi:10.1593/tlo.12280

72. Durante M, Brenner DJ, Formenti SC. Does heavy ion therapy work through the immune system? Int J Radiat Oncol Biol Phys (2016) 96:934-6. doi:10.1016/j.ijrobp.2016.08.037

73. Hodge JW, Guha C, Neefjes J, Gulley JL. Synergizing radiation therapy and immunotherapy for curing incurable cancers: opportunities and challenges. Oncology (Williston Park) (2008) 22:1064-70.

74. Rosell R, Carcereny E, Gervais R, Vergnenegre A, Massuti B, Felip E, et al. Erlotinib versus standard chemotherapy as first-line treatment for European patients with advanced EGFR mutation-positive non-small-cell lung cancer (EURTAC): a multicentre, open-label, randomised phase 3 trial. Lancet Oncol (2012) 13:239-46. doi:10.1016/S1470-2045(11)70393-X
75. Crowley E, Di Nicolantonio F, Loupakis F, Bardelli A. Liquid biopsy: monitoring cancer-genetics in the blood. Nat Rev Clin Oncol (2013) 10:472-84. doi:10.1038/nrclinonc.2013.110

76. Meng X, Loo BW, Ma L, Murphy JD, Sun X, Yu J, et al. Molecular imaging with 11C-PD153035 PET/CT predicts survival in non-small cell lung cancer treated with EGFR-TKI: a pilot study. J Nucl Med (2011) 52:1573-9. doi:10.2967/jnumed.111.092874

77. Ohri N, Duan F, Snyder BS, Wei B, Machtay M, Alavi A, et al. Pretreatment 18F-FDG PET textural features in locally advanced non-small cell lung cancer: secondary analysis of ACRIN 6668/RTOG 0235. J Nucl Med (2016) 57:842-8. doi:10.2967/jnumed.115.166934

78. Aerts HJ, Velazquez ER, Leijenaar RT, Parmar C, Grossmann P, Cavalho $\mathrm{S}$, et al. Decoding tumour phenotype by noninvasive imaging using a quantitative radiomics approach. Nat Commun (2014) 5:4006. doi:10.1038/ ncomms5006

79. Shibaki R, Akamatsu H, Fujimoto M, Koh Y, Yamamoto N. Nivolumab induced radiation recall pneumonitis after two years of radiotherapy. Ann Oncol (2017) 28:1404-5. doi:10.1093/annonc/mdx115

80. Flaum N, Lorigan P, Whitfield GA, Hawkins RE, Pinkham MB. Integrating radiation therapy with emerging systemic therapies: lessons from a patient with cerebral radionecrosis, spinal cord myelopathy, and radiation pneumonitis. Pract Radiat Oncol (2016) 6:110-3. doi:10.1016/j.prro.2015.10.008

81. Bezjak A, Paulus R, Gaspar L, Timmerman R, Straube W, Ryan W, et al. Primary study endpoint analysis for NRG Oncology/RTOG 0813 trial of stereotactic body radiation therapy (SBRT) for centrally located non-small cell lung cancer (NSCLC). Int J Radiat Oncol Biol Phys (2016) 1:5-6. doi:10.1016/j. ijrobp.2015.10.040

Conflict of Interest Statement: The author declares that the research was conducted in the absence of any commercial or financial relationships that could be construed as a potential conflict of interest.

Copyright (อ) 2017 Ohri. This is an open-access article distributed under the terms of the Creative Commons Attribution License (CC BY). The use, distribution or reproduction in other forums is permitted, provided the original author(s) or licensor are credited and that the original publication in this journal is cited, in accordance with accepted academic practice. No use, distribution or reproduction is permitted which does not comply with these terms. 